of establishing national reserves for the maintenance of the natural fauna and flora, and that these should be set up in more secluded areas and controlled and administered by experts. A request was also made for the beginning of a biological survey of Australia.

Excitement was lent to the proceedings of the Congress by two stimulating lectures given by $\mathrm{Mr}$. H. G. Wells, who had been invited specially to Australia for the meeting. Mr. Wells was provocative, especially with his paper on "The Poison called History" which was delivered to the History Section; but attended by a great crowd, and much appreciated.
Other visitors specially invited from England were Sir John Flett, Sir John Russell, Prof. F. T. Brooks and Prof. N. V. Sidgwick. Prof. Brooks gave a lecture on "Epidemic Plant Diseases" and Prof. Sidgwick read a paper bearing the title "Multiple Links". Another visitor from England, Sir George Simpson, read a paper on "Electricity in Thunder Clouds" to Section A, and delivered a public lecture on "Iee Ages".

The Congress was an unqualified success, despite the terrific heat $\left(109^{\circ}\right.$ in the shade one day), all records for Canberra being broken. W. J. DAKIN.

\title{
The Underground Water of London
}

\begin{abstract}
$A \mathrm{~N}$ excellent and serviceable memoir on "The A Water Supply of the County of London from Underground Sources", prepared by Dr. Stevenson Buchan, has been issued by the Department of Scientific and Industrial Research (H.M. Stationery Office. $6 s .0 d$. net). It is primarily a supplementary development of the "Records of London Wells" by Messrs. Barrow and Wills, published by the Geological Survey in 1913, restricted in purview to the county boundaries and brought up to date by means of the later accumulation of information. Records of 1,080 wells are set out in detail, of which 565 make their appearance for the first time. More than one hundred of the records of strata are fully described, the remainder being in abstract form.
\end{abstract}

The memoir is commendably complete, for it gives a résumé of the history of London's water supply, with many interesting facts about the early and primitive sourees from which it was drawn. So far back as 1236 , water was brought to the City through conduits from wells and springs outside the populated area. Tyburn, Paddington, Hackney and Hampstead all contributed their quota during the period 12361549. In 1582, water was obtained from the Thames by a pump actuated by water wheels located at London Bridge. Then in 1613, the new river system was inaugurated, bringing supplies from springs in Hertfordshire, because at the beginning of the seventeenth century, the tributary streams through the town had become choked and partly buried, and few of the public wells remained. Towards the end of the eighteenth century, the first deep wells were sunk; but the movement did not make much headway for several years. Water companies were formed about the same period to draw supplies from the Thames and its tributaries, and to store it in reservoirs. These external surface sources now constitute the main feeder system.

As regards the wells, the early shallow borings were sunk to the sand and gravel terraces on the river banks. When, in course of time, these became polluted, deeper borings were made through the London Clay to the strata known as the Reading Beds and Thanet Sands, containing water either percolating from surface outcrops outside London or derived from the underlying chalk, which, acting as an enormous reservoir, to-day is the most important water-bearing bed under London. The water-level, however, is falling both in the sands (some supplies are actually exhausted in the northern area) and in the chalk, whence water is being extracted more rapidly than the rate of replenishment by the extremely slow flow which is alone possible under existing subterranean conditions.

As examples, the memoir mentions the wells close to the National Gallery, which, at one time, supplied the fountains in Trafalgar Square, many of the public buildings in Whitehall, the old Millbank Prison and the Houses of Parliament. Between 1844 and 1911, the water-level had fallen $127 \mathrm{ft}$., and the wells were shortly afterwards abandoned. Another well, which used to feed the Serpentine and its fountains, the Palace Lake and the lake in St. James's Park, had its water-level lowered by $96 \mathrm{ft}$. in the space of fortyeight years and was also abandoned.

With the increase in pumping and the growing competition for supplies, the lowering of the waterlevel is becoming more and more pronounced. New wells in the district of ehalk outcrop are tapping quantities of water which might otherwise travel towards the centre of London. Moreover, land drainage over the surface of the outcrop is now more efficient and the quantity of rainfall available for absorption correspondingly diminished, both from this cause and also from the increase in impermeable surface due to building and road making. Finally, the prolonged periods of drought in recent years have exercised their adverse influence in preventing the recovery of lost levels. With the depression in level, there has been manifested an increase in salt water pollution of many wells down river from Bermondsey.

Wells have been sunk below the chalk to the Old Red Sandstone, the deepest of which is a well at Stonebridge Park, with a depth of 2,225 ft. Unfortunately, after encountering traces of oil and gas from levels below 1,500 ft., the final yield was small and distinctly saline.

The following conclusions are drawn as to the future of supplies from the chalk-sand reservoir under the County of London. The fall in water-level is likely to continue and the annual rate of depression to increase. If a uniform, or slightly increased rate of fall be assumed, the water will reach the base of the Upper Chalk in many parts of London during the present generation, and, at this level, it is probable that a negligible amount of water will be obtainable from the wells. There is, moreover, little likelihood of a supplementary supply from the beds below the Chalk under London.

Brysson Cunningham. 